\title{
La tradició dels lletovaris literaris catalans: el cas de Joan Basset
}

\author{
Alba Romanyà \\ Universitat de Barcelona \\ albaromanva@gmail.com \\ https://orcid.org/O000-0002-6713-739X \\ Received: I2/05/202I; accepted I2/O7/2O2I \\ DOI: https://doi.org/10.7203/MCLM.8.20894
}

The Catalan tradition of literary electuaries: the case of Joan Basset

Abstract

A literary electuary, Iletovari in Catalan, is a poem that adopts some of the characteristics of medical recipes. Even though this term is used in many studies with naturality, the tradition of this type of poetry has not been described or studied as a whole. In this paper, the main attributes of this genre are exposed, and a provisional corpus of poems associated with it is put forward. Finally, the most outstanding work of that tradition, Joan Basset's Lletovari, is characterised.

KEYWORDS

Medical recipes; electuaries; Joan Basset; literary genres; medieval Catalan poetry

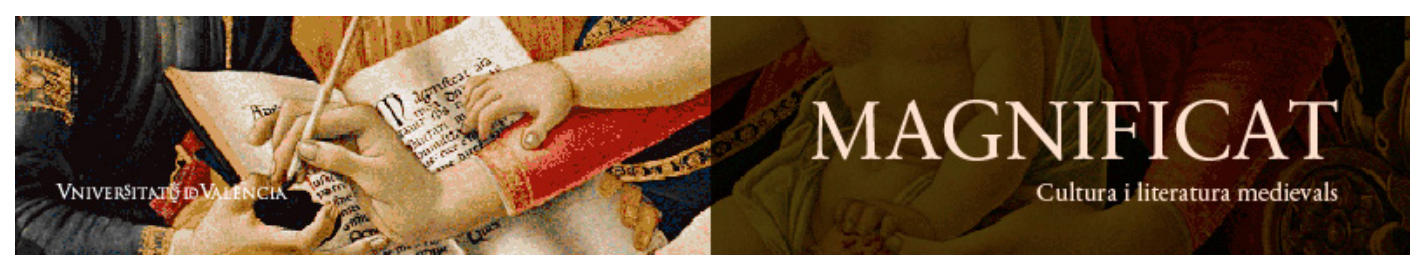

Magnificat Cultura i Literatura Medievals 8, 202I, Io9-126. http://ojs.uv.es/index.php/MCLM

ISSN 2386-8295 
RESUM

Un lletovari o electuari literari és una composició poètica que adopta forma de recepta mèdica. Malgrat que el terme «lletovari» s'ha utilitzat amb naturalitat en diversos estudis, aquesta tradició s'ha descrit poques vegades i no s'han estudiat les obres que l'integren com a conjunt. En aquest article es perfilen les característiques més comunes del gènere, se n’assaja una nova definició i se’n proposa un corpus de textos. A més, s’analitza detalladament el Lletovari de Joan Basset, que és la peça més rellevant d’aquesta tradició.

PALABRAS CLAVE

Receptaris mèdics, lletovaris, Joan Basset, gèneres literaris; poesia catalana medieval

Alba Romanyà. 202I. 'La tradició dels lletovaris literaris catalans: el cas de Joan Basset', Magnificat Cultura iLiteratura Medievals, 8: Io9-I26, DOI: https://doi.org/IO.7203/MCLM.8.20894 (c) Br

Aquest article ha comptat amb una ajuda per a la Formació de Personal Investigador (FPI), atorgada pel Ministeri de Ciència i Innovació en la convocatòria del 2org i vinculada al projecte d'investigació Narpan II: Corpus Digital de Textos Catalanes Medievales y Renacentistas (PGC2OI8-0954I7-B-C6I), finançat per la Generalitat de Catalunya a través de l'AGAUR.

\section{TAULA DE CONTINGUTS}

I. Introducció - III

I.I L'origen: de la ciència a la literatura - II2

I. 2 Els lletovaris catalans: una tradició dispersa - II3

2. Una proposta de corpus de lletovaris catalans - II4

2.I Lletovaris per curar el mal d'amor - II 4

2.2 Dues paròdies del gènere del lletovari i de la professió mèdica - II6

2. 3 Tres electuaris morals - II7

${ }_{3}$ El Lletovari de Joan Basset i la seva connexió amb l'Espill de Jaume Roig - I2O

4 Una nova definició del gènere - I22

${ }_{5}$ Obres citades - I25 


\section{b米}

\section{Introducció}

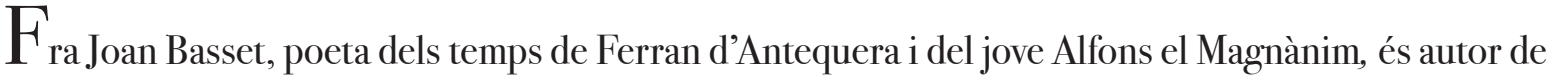
vint-i-una composicions molt diverses conservades únicament en el Cançoner Vega-Aguiló (BC mss. 7 i 8). Basset cultivà una gran quantitat de gèneres: danses, cançons marianes i polítiques, cobles esparses amoroses, endevinalles, un prosímetre, maldits i el que serà el punt de partida del present article, un lletovari tetrasil-làbic de to satíric. ${ }^{\mathrm{I}}$

En sentit estricte, un lletovari, modernament anomenat electuari, és una «preparació farmacèutica feta amb pólvores, polpes, etc., barrejades amb mel, xarop o un altre component, formant una massa pastosa». (DIEC s.v. electuari). Així i tot, més enllà del seu sentit farmacològic, el terme també dona nom a un grup de composicions en vers que es detecten a partir de la segona meitat del segle XIII i que utilitzen la imatge de la malaltia i del remei per parlar metafòricament de problemes diversos -físics, imaginaris o al-legòrics-i proposar-hi solucions. Aquestes composicions poden abordar diferents temes i escriure's amb finalitats gairebé oposades, però totes tenen un fil conductor que les interrelaciona: adopten una estructura de recepta mèdica i donen instruccions per ajudar a curar un destinatari sofrent.

El Lletovari de Joan Basset és una peça rellevant dins d'aquesta tradició: no només perquè és una obra molt paradigmàtica del que considerem les característiques més comunes del gènere, sinó perquè, a més, és l'única peça conservada que utilitza el metre tetrasillàbic apariat per fer sàtira contra les dones i això el converteix en un dels precedents de l'Espill de Jaume Roig (Bohigas I983: 33). Escrit a principis del segle XV, el Lletovari de Basset és una peça de I95 versos que s'adreça, com un remei mèdic, al poeta Guerau de Maçanet, ${ }^{2}$ malalt d'amor.

Malgrat que sovint s'ha parlat de la tradició dels «lletovaris», «receptaris» o «electuaris» literaris, poques vegades se'ls ha dedicat l'atenció que es mereixen per entendre'ls com a gènere i per definirlos amb uns límits clars. L'objectiu d'aquest article és, justament, contextualitzar les composicions que s'han considerat o que es podrien considerar lletovaris, proposar-ne un corpus indicatiu i una classificació, observar-ne les característiques principals i assajar-ne una definició de gènere. Finalment, volem analitzar especialment el Lletovari de Joan Basset i la seva relació amb l'Espill de Jaume Roig.

I. Aquest article està basat en el treball de final de màster Materials per a l'edició i estudi del Lletovari de Joan Basset - presentat el 2020 com a part del màster d'Estudis Avançats de Llengua i Literatura Catalanes (Universitat Autònoma de Barcelona i Universitat de Barcelona)- i s'inscriu en el marc d'una tesi doctoral sobre el conjunt de l'obra de Joan Basset dirigida per Lola Badia i Anna Alberni a la Universitat de Barcelona.

2. Poeta de principis del segle Xv del qual només se’n conserven dues composicions transmeses pel Cançoner VegaAguiló: una dansa i una tençó amb Gabriel Ferrús (Torró 20I4: 312). S’ha suposat que el nom de Guerau de Maçanet devia ser un pseudònim: Jaume Torró, seguint una hipòtesi de Josep Romeu (I994: 83-IOI), identifica el poeta amb Guerau de Rocabertí, senyor de Maçanet de Cabrenys i casat amb Joana de Pròixida (Torró 20I4: 3I3). De tota manera, la seva identitat encara genera certs dubtes (Alberni 2003:9). 


\section{I.I Lorigen: de la ciència a la literatura}

L'aparició del gènere dels receptaris mèdics s'ha d'entendre en el context de transformació de l'Europa occidental del pas de l'alta edat mitjana a la baixa. El creixement de la burgesia va propiciar unes noves formes d'institucionalitzar i elaborar el saber que es van materialitzar, entre altres coses, en el sistema universitari. Fins llavors, l'exercici de la medicina havia anat a càrrec de clergues i de pràctics sense coneixements acadèmic; però a partir de les últimes dècades del segle XIII es va organitzar com un sistema regulat que, en principi, havia de quedar en mans dels universitaris. Amb tot, en paral-lel al sistema oficial, els professionals de la salut extrauniversitaris -barbers, cirurgians, metgesses- van continuar practicant el seu ofici segons els mètodes tradicionals i també, en alguns casos, amarant-se de fonts acadèmiques (Cifuentes 2002: 28-34).

Alhora que augmentava l'interès dels laics pel saber, s'ampliava l'accés a la lectura i a l'escriptura. La circulació de textos científics i tècnics va incrementar-se perceptiblement per cobrir les noves demandes dels professionals de la salut i de les d'altres capes de la població que hi tenien interès. D'aquesta manera, la medicina va deixar de ser una disciplina reservada als especialistes i es va tornar accessible. Com que el públic d'aquesta mena de textos no solia trobar-se còmode amb el llatí, la informació mèdica també va començar a circular en vernacle (Cifuentes 2002: 30).

El receptari mèdic, entès com una compilació de remeis, és un nou gènere que cal relacionar amb les necessitats d’aquesta nova societat, cada vegada més medicalitzada. Al seu article «El receptari mèdic baixmedieval i renaixentista: un gènere vernacle» (20I6), Lluís Cifuentes comenta la importància d'aquest gènere en la història de la ciència i avisa que no s'ha de confondre el terme «receptari mèdic» amb el de «receptari». En efecte, el mot «receptari» era un tecnicisme que es feia servir gairebé exclusivament per referir-se al registre de receptes de l'apotecari: no era, doncs, un manual terapèutic, sinó un llibre de gestió que ajudava a comptabilitzar les receptes que aquest pràctic elaborava i expedia per als seus pacients. En canvi, el terme «receptari mèdic» es referia al «recull de receptes i d'altres obretes breus que es consideren útils per a la prevenció i la terapèutica de determinades malalties» (Cifuentes 20I6: II4 i II6). Són aquests receptaris mèdics els que resulten especialment rellevants per a la cultura de l'època perquè no només van deixar empremta en la història de la ciència, sinó que també van impregnar el món de la literatura.

Certament, els reculls de receptes van passar a formar part de la vida quotidiana d'algunes capes de la societat: els compilaven tant els guaridors sense formació universitària com els interessats a cuidar-se la salut en l'àmbit domèstic. Els lletovaris literaris deriven d'aquest gènere mèdic: no només perquè, com el seu model, donen instruccions de salut, sinó perquè, en alguns casos, utilitzen terminologia típica de les professions mèdiques - pràctica que subratlla que el seu públic estava familiaritzat amb aquest camp semàntic (Valsalobre 2005: 39).

Així i tot, cal advertir que, sovint, la proximitat dels lletovaris literaris amb el món de la medicina és molt relativa. Per damunt de tot, són obres de ficció i, en molts casos, utilitzen una terminologia mèdica al-legòrica, imaginària o estrambòtica. És més, hi ha poemes que pretenen ser una recepta mèdica, però que no acaben parlant de medicina -o que només ho fan de manera molt secundària. El cas del Lletovari de Joan Basset en pot ser un exemple: la composició cita quatre metges famosos de l'època -Averrois, Avicenna, Mondenís ${ }^{3}$ i Galè- i alguns ingredients comuns de l'apotecari com la momia ${ }^{4}$ o el greix de porc. Amb tot, el tema central del poema és tant l'amor com els grans

3. L'identifiquem amb Mondino de’ Liuzzi, anatomista bolonyès dels segles XIII-XIV. Agraïm aquesta identificació a Lluís Cifuentes.

4. 'Nom que es donava a la carn putrefacta i a la substància exsudada dels cadàvers embalsamats, a les quals s'atribuïen propietats curatives' (DCVB s. v. momia). 
desavantatges d'estimar les dones. Així, malgrat aquesta connexió amb el món mèdic, el poema no deixa de ser un divertiment literari.

\section{2 Els lletovaris catalans: una tradició dispersa}

Si la tradició dels lletovaris literaris no ha rebut mai l'atenció que es mereix, potser es deu a la gran diversitat de les seves composicions -de temes, formes i intencions molt diferents-i a la seva dispersió al llarg del temps. En la tradició catalana, el poema més antic que s'ha detectat que adopta fórmules mèdiques per fer literatura és La recepta de xarop de Cerverí de Girona, d’abans del I267, però després se'n troben mostres als segles XIV, XV i principis del XVI. A aquesta heterogeneïtat cal afegir que, a l'època, no es percep una consciència de gènere que agrupi aquestes obres sota unes mateixes regles de composició: mai no van ser descrites als tractats retòrics de finals del XIII i principis del XIV i, de fet, tampoc no es van aglutinar sota un mateix terme que les definís. Alguns poemes són descrits a les seves rúbriques com a «lletovaris»o «receptes», però d'altres són anomenats «consells», «consolacions», «medicines», «avisos» o altres variants. Malgrat que moltes d'aquestes designacions expressen una mateixa intenció d'auxiliar algú, és difícil de veure-hi un terme unitari que empari aquestes receptes literàries sota un mateix paraigua.

Aquesta manca d'institucionalització del gènere s'explica pel caràcter tardà dels lletovaris i per la seva adscripció a unes circumstàncies culturals concretes: és només quan el receptari mèdic es popularitza que es comencen a adoptar les seves fórmules com a model per fer literatura -és a dir, a la segona meitat del segle XIII. Així, els poemes amb forma de recepta es van començar a cultivar coetàniament o poc abans de la redacció dels tractats retòrics. A més, si tenim en compte que la majoria de gèneres que s’hi caracteritzen són els que ja es cultivaven en l’època trobadoresca clàssica, és fâcil d'entendre per què els lletovaris no es van percebre com una tipologia textual modèlica que calgués descriure.

Així i tot, les composicions que prenen forma de recepta tenen prou punts en comú perquè darrerament la bibliografia crítica hagi parlat de la tradició o del gènere dels lletovaris literaris. ${ }^{5} \mathrm{~A}$ més, el terme «lletovari» s'ha emprat amb naturalitat per etiquetar obres que es presenten com a receptes mèdiques. Amb tot, malgrat aquesta intuïció d'unitat, la tradició poques vegades ha estat descrita amb propietat ni s'han estudiat les obres que la componen com a conjunt. Una de les poques publicacions d'aquestes característiques que s'ha localitzat és l'article «Apotecaris i receptes en la literatura catalana antiga» (2005), de Pep Valsalobre, que descriu algunes de les composicions més representatives de la tradició i n’assaja una definició que abraça les «composicions poètiques basades en la transposició metafòrica dels remeis del cos als de l'ànima per guarir el mal d'amor» (Valsalobre 2005: 40). També s'apropa al gènere Rosanna Cantavella en un article titulat «Terapèutiques de l'amor hereos a la literatura catalana medieval» (I993), en el qual afirma que els lletovaris són «obres literàries catalanes que tenien en comú de presentar-se com a remeis d'amors, però que en comptes d'invocar Ovidi, es declaraven de filiació mèdica» (Cantavella I993: r98).

Aquestes definicions són un bon punt de partida, però convé matisar-les perquè els diferents textos que s'han inclòs dins de la tradició dels lletovaris, o s’hi han relacionat d'alguna manera, són molt diversos i no es limiten a parlar d'amor. Per evitar d'excloure, ja d'entrada, obres que podrien

5. Vegeu, per exemple, l'article d'Antònia Carré (202I: I48) en el qual ja s'escateix la relació entre el lletovari i l'antidotari de l'apotecari, i s'emfatitza l'ús recurrent de formes medicamentoses com ungüents, xarops, juleps o emplastres en aquestes composicions. 
formar part del gènere, volem ampliar els límits conceptuals d'aquesta tradició i proposar-ne una nova definició que sigui més inclusiva amb els espècimens textuals conservats.

\section{Una proposta de corpus de lletovaris catalans}

$\mathrm{U}_{\mathrm{n}}$ na anàlisi atenta del conjunt d'obres que ja han estat catalogades com a lletovaris o que, en algun moment, s'han relacionat amb aquesta tradició ${ }^{6}$ ha permès detectar tres característiques que, en major o menor mesura, es donen en molts aquests textos i que podrien ser significatives per descriure el gènere amb més precisió: (I) la majoria d'aquestes composicions prenen l'estructura d'una recepta mèdica i es relacionen amb el gènere del receptari mèdic; (2) presenten un narrador que adopta el rol de metge i que explica com solucionar els problemes de salut d'un destinatari malalt concret; (3) moltes d'aquestes obres utilitzen terminologia mèdica -real o fictícia- o fan referències al món de la medicina.

Aquests tres trets han estat el criteri de selecció de nous textos que fins ara no s'havien llegit des d'aquesta perspectiva, però que encaixen en aquesta tradició. Els poemes que la bibliografia ja havia relacionat amb el gènere i aquestes noves incorporacions formen un corpus de nou obres molt heterogeni que és el punt de partida per a la nova definició del lletovari literari. Convé advertir que hem adoptat el terme gènere sense abordar la discussió teòrica sobre l'abast i les implicacions del mot. Ens limitem a constatar que, seguint la diferenciació de Riquer (I975: 45 i 49) a propòsit dels gèneres trobadorescos condicionats per la seva versificació i pel seu contingut, els lletovaris s'adscriuen en aquest segon grup. El nucli que cohesiona tots aquests textos no és una forma poètica concreta, sinó una voluntat comuna de transmetre coneixements útils per solucionar problemes mèdics. Un nucli que, com reiterem, connecta aquestes composicions amb els receptaris mèdics.

El corpus aplegat permet un estudi de conjunt dels diferents lletovaris conservats i admet classificar-los en tres grups temàtics. En primer lloc, hem agrupat els poemes que adopten la metàfora de la malaltia i la cura per parlar de l'amor i de la seva solució. Són, potser, els lletovaris més prototípics i connecten directament amb les definicions del gènere que proposaven Cantavella i Valsalobre. En segon lloc, hem recollit els poemes que ja no tenen l'amor com a tema central, sinó que se centren en la paròdia dels lletovaris amorosos o de la professió mèdica. Finalment, hem reunit tres obres que adopten el motiu de la recepta i del poeta-metge per parlar de qüestions morals.

\section{I Lletovaris per curar el mal d'amor}

La malaltia i la curació han servit recurrentment per crear analogies en diferents àmbits literaris. Parlar de malalts i metges per referir-se a enamorats i consellers ha estat un símil comú en la literatura de tots els temps que, a l'edat mitjana, va anar de bracet amb la idea que el mal d'amor era realment una patologia, codificada pels tractats científics. Al segle II, Galè va observar-ne els símptomes i els va recollir en obres mèdiques que, més tard, van ser represes per metges bizantins i àrabs. Al segle XI, Constantí l'Africà va reintroduir aquest saber a Itàlia a través del seu Viaticum, que donava el nom d'amor hereos a la malaltia de l'amor -que solia afectar el cervell i altres òrgans (Wack I990: 7). El seu tractat va servir de base per a moltes altres obres mèdiques posteriors que en van

6. Hem tingut en compte el conjunt de la poesia trobadoresca i de la lírica catalana medieval. 
descriure les causes, els símptomes i els tractaments (McVaugh-Giralt 2OII: II). Des de l'antiguitat, la malaltia d'amor també ha format part de la literatura, que ha jugat tant amb la idea de la seducció com a disciplina, com amb el tractament mèdic de l'amor (Cabré I993: 52). Plutarc i Valeri Màxim ja relataven la història d'un metge que havia diagnosticat la patologia d'amor a un pacient observant-li l'alteració del pols i Ovidi parlava d'aquesta afecció a l'Ars amandi i els Remedia amoris (Cantavella I993: I9I).

El lletovari amorós és una modalitat específica d’aquesta tradició literària: com moltes altres obres, parla d'aquest mal com si fos una malaltia, però amb la particularitat distintiva que adopta la forma i els trets d'una recepta mèdica. Com diu Cantavella (I993: I98), «l'autofiliació mèdica és el detall que distingeix aquestes obretes dins un conjunt europeu, més ampli, de consultes i consells sobre el guariment amorós, hereus de la tradició literària ovidiana i de to més seriós». En la tradició catalana, els poemes d'aquestes característiques que hem localitzat són pocs i estan datats entre la segona meitat del segle XIV i l'inici del segle XV.

Primer, el Mald'amor o Consell d'amor de Pere March és un poema de 302 versos en forma d'epístola, escrit a la segona meitat del segle XIv. El poeta, en funcions de metge, aconsella una solució mèdica a una dama que pateix aegritudo amoris sense ser-ne conscient (Cabré 1993: 5I). Que l'autor decideixi enviar el seu remei per carta es justifica per una anècdota que s'explica a l'inici del poema: mentre passeja, Pere March es troba un matrimoni que li demana que examini la dona, que està malalta. March fa el que li manen, no sense recrear-se en els tocaments de rigor, i anuncia que comunicarà el seu diagnòstic a la dama per via epistolar. Com que el protagonista ja ha advertit que la pacient pateix de la malaltia d'amor, seria del tot inescaient revelar-la davant del marit, que en tot moment es presenta com un babau (Cabré i993: 53).

Aquest poema es pot emmarcar fâcilment dins de la tradició dels lletovaris: no només perquè el protagonista adopta el rol de metge, sinó, sobretot, perquè la peça proposa un tractament mèdic -conductual, en aquest cas- a la malaltia de l'amor. La solució que Pere March dona a la dama no serà altra cosa que demanar-li que es desinhibeixi i es lliuri a l'amor adúlter. Tan sols per aquest desenllaç es pot constatar que es tracta d'un poema de to jocós que identifica la malaltia d'amor amb la fina amor i que proposa com a remei la seducció i l'acompliment dels desitjos (Cabré i993: 52-53).

Ja al segle XV, al I423, Lluís Icart va escriure un altre lletovari anomenat Consolació o avís d'amor que també segueix la tradició dels receptaris que proven de curar els efectes nocius d'estar enamorat. Conservat al Cançoner Vega-Aguiló, es tracta d'un poema extens, de 523 versos, que proposa un remei a un amic del poeta que està malalt. En aquest sentit, es pot relacionar fâcilment amb el Lletovari de Joan Basset, que també va destinat a un amic que pateix d'amors. Conservat al mateix Vega-Aguiló i escrit entre el I4I4 i el I424, el poema de Basset també ressegueix els efectes de l'amor com si fossin els símptomes d'una malaltia (Bohigas i988: 25)

Cabré (I993: 54) ja remarcava que el Mal d'amor de March, la Consolació o avís d'amor d'Icart i el Lletovari de Basset segueixen un patró molt semblant. Tots tres són poemes pretesament mèdics que miren d'ajudar algú que està enamorat. A més, tenen la idea comuna que la ciència és insuficient per curar una malaltia tan greu i, en lloc de recomanar remeis farmacològics, acaben oferint prescripcions conductuals que no són altra cosa que consells comuns dins del marc de la fina amor (Valsalobre 2005: 42).

En aquest sentit, és significatiu que Basset assenyali que els metges més coneguts de l'època -Galè, Avicenna o Averrois- no serveixen per curar l'amor i que apunti que, qui cal consultar realment, són els mateixos poetes, que també acaba bandejant (Bohigas I988: 25). Amb tot, malgrat les seves similituds, Cabré (I993: 54) remarca que els remeis proposats en cada cas són diferents i que, de fet, revelen un canvi de mentalitat sobre com abordar els mals d'amor. En el poema de March s'opta pel sensualisme i per l'acompliment d'un amor adúlter de caràcter lúdic que connecta 
amb la fina amor més desinhibida. En canvi, en el d'Icart s'insta el lector a acceptar el turment de l'amor perquè es considera una passió ennoblidora. Es recomana, això sí, que hom procuri posar les esperances en dames que no siguin falses i que no es reveli el secret de la passió d'amor, per precaució. La ideologia del poema, doncs, no deixa de ser la de l'amor com a virtut ennoblidora amb un caire sentimental. Finalment, en el Lletovari de Basset es recomana al malalt que s'allunyi de l'amor després d'una llarga diatriba contra les dones i els seus paranys. De fet, aquesta tercera composició fa explícita una reprovació de la fina amor que, en més o menys mesura, ja era present en les altres dues.

La naturalesa misògina i el metre tetrasil-làbic del Lletovari de Joan Basset conviden a llegir-lo com un dels precedents de l'Espill de Jaume Roig (Bohigas I983: 33). Els punts en comú entre totes dues obres són palpables: no només comparteixen el tema acusadament antifemení i el metre que escullen per expressar-lo, sinó que totes dues es presenten com a remeis mèdics contra l'amor.? En efecte, l'obra de Roig és una autobiografia fictícia que vol servir d'advertiment als joves, en general, i a Baltasar Bou, en particular, contra els mals de l'amor i de les dones. Per fer-ho, utilitza terminologia mèdica de manera recurrent i associa, sovint, l'amor i la proximitat de les dones amb els símptomes d'una malaltia. En aquest sentit, cal tenir present que el Jaume Roig escriptor exercia de metge i que, per tant, parlava de medicina amb més coneixement de causa que no pas Basset. Com que l'Espill compleix algunes de les característiques més comunes del gènere dels lletovaris -vol ser un remei, el seu escriptor és metge i utilitza el camp semàntic de la medicina-, podem discutir si convé d’incloure'l en aquesta tradició (vegeu §3).

\subsection{Dues paròdies del gènere del lletovari i de la professió mèdica}

A continuació, analitzem dues composicions humorístiques que aprofiten les instruccions del preparat farmacèutic per fer befa de qüestions diverses i, potser, fins i tot, per parodiar els lletovaris amorosos. Per ordre cronològic, la primera composició catalana que compleix aquestes característiques és La medicina feta per en Bernat Metge apropiada a tot mal, escrita entre el I396 i el I397. Només pel títol de l'obra, ja podem advertir la connexió entre el poema i la tradició dels lletovaris. En I25 octosíl-labs apariats, el poeta recepta un preparat farmacèutic paròdic al seu amic mossèn Bernat que, com diu ell mateix, està malalt de «fastig» (tedi) i de «tristor» i ha quedat reclòs a casa seva (Cabré 20I4: 197).

Fill de l'apotecari Guillem Metge, Bernat Metge va heretar la biblioteca de la botiga del carrer dels Especiers i aquí hi devia aprendre els rudiments de la preparació de lletovaris i de xarops (Carré 2O2I: I 45). El seu poema explica detalladament com s'ha de preparar una recepta i, en aquest procés, entre el joc de demanar la utilització de productes impossibles, com el «badall d'estornell» o el «fum de palla remullada», també menciona elements autèntics i utilitzats àmpliament pels especiers (Cabré 2OI4: 197). Així, a banda d'atrevir-se a recomanar l'ús de productes derivats de personatges bíblics, com poden ser les «llàgrimes de David», també cita ingredients tan comuns com el «garangal», que el DCVB (s. v. galanga) defineix com a «rizoma de diferents plantes zingiberàcies d'origen oriental, especialment l'Alpinia officinarum».

Cap al final de la carta al seu amic, Metge també recomana un seguit de comportaments saludables comunament coneguts a l'època: fer una bona dieta, dinar d'hora, fer una digestió adequada (per exemple, passejant) i no anar a dormir tard. Gràcies a aquest règim de vida i al xarop que li ha receptat, el seu amic Bernat hauria de ser capaç de deixar enrere el seu estat de mala salut i

7. Així i tot, cal tenir present que l’obra de Roig és molt més complexa i beu, al mateix temps, de molts altres referents. 
tornar a l'alegria. Amb tot, el to del poema fa entreveure que el malalt no està gens greu i que, de fet, potser té una malaltia tan fictícia com el tractament que l'ha de curar (Cabré 20I4: 198).

Pel seu to lúdic, el poema de Bernat Metge es pot entendre com una paròdia dels poemes-recepta que miren de resoldre malalties amoroses. Alhora, i si es posa l'accent en la broma contínua que es fa de la terminologia farmacèutica, també es pot entendre com una burla de l'ofici de l'apotecari medieval (Valsalobre 2005: 42). Així dones, es tracta d'un poema que s'allunya de l'exemple més prototípic del lletovari amorós i s'acosta a la paròdia d'aquestes mateixes obres i de l'ofici de metge en general.

En segon lloc, hem seleccionat un altre poema, titulat Lletovari, que es conserva al Cançoner de l'Ateneu (Barcelona, Ateneu Barcelonès, ms. I). Es tracta d'una obra anònima de la segona meitat del segle XV que, en la línia del poema paròdic de Metge, presenta una derivació humorística del gènere, tot i que, aquesta vegada, en lloc de presentar ingredients estrafolaris o imaginaris per a una malaltia també inventada, es recrea en l'escatologia i l'obscenitat (Valsalobre 2005: 42).

El poema va adreçat a un personatge anomenat mossèn Joan, que no està bé de salut. El poeta, adoptant, com sempre, el rol de metge, li explica una recepta que l’ha de curar molt més que no pas si cometés adulteri. Aquesta al-lusió pot fer pensar que l'autor coneixia els lletovaris amorosos i que els volia parodiar. Si recordem el Mal d'amor de Pere March, per exemple, ja advertim que, en aquella composició, el metge recomanava a la malalta que seguís els impulsos del seu amor i que, per tant, es lliurés a l'adulteri. Aquesta vegada, però, el poeta té un remei encara millor que els plaers de l'amor i proposa un refrigeri de composició ben diversa: des d'excrements de diferents mides i matèries fins a rots o suc de dins de les aixelles; i tot plegat s'ha de beure calent i de matines.

Malgrat que la deformació grotesca del gènere és evident, el cert és que compleix tots els ingredients per relacionar-se amb la tradició del lletovari. No només perquè descriu una recepta amb tot luxe de detalls, sinó també perquè el protagonista adopta el rol de metge. L'al-lusió a l'adulteri encara és més indicadora de la relació que es dona entre aquest poema i la tradició que deu voler parodiar. Això pot fer pensar que els lletovaris amorosos podien ser un gènere consolidat $i$ amb moltes més composicions que les tres mostres que ens han pervingut. ${ }^{8}$

\section{3 Tres electuaris morals}

La forma de recepta mèdica no només s'ha utilitzat per parlar d'amor i burlar-se dels metges, sinó que també ha sigut un recurs al-legòric per tractar dels problemes morals dels homes i de les seves solucions. El primer lletovari d'aquestes característiques que hem localitzat també és el més antic: es tracta de La recepta de xarop de Cerverí de Girona, compost quan l'autor es trobava a cavall entre el servei dels Cardona i de l'infant Pere, abans del I267. El poema, de Io6 versos, explica una història al-legòrica en la qual el poeta, anomenat Cerverí, adopta el rol de metge d'amor (Cabré 20I3: 266). Mentre passeja, el poeta es troba un personatge que es presenta com a Cortezia i que

8. En aquest apartat de lletovaris paròdics, no volem deixar de mencionar les dues cobles esparses de Pere Antoni i de Joan de Masdovelles. «Trepodion baracasin xaxundi / Breus trups gracum de carapintasen», comença Pere Antoni. Al seu torn, Masdovelles respon amb una cobla del mateix to que en manté la mètrica i la rima: «qui padanam farup damiracundi / abximalich tribentari jasen» (RIALC). Escrites a finals del segle Xv i conservades al Cançoner de l'Ateneu Barcelonès, aquestes cobles semblen ser un joc d'endevinalles en clau. De fet, la major part de poesies de Joan de Masdovelles juguen amb aquest gènere de l'enigma i, per tant, no seria estrany que les cobles amaguessin un significat ocult que caldria desxifrar (Riquer I964, III: I45-46). Malgrat que no tenim constància que ningú hagi descobert què volen dir, Lluís Cifuentes suggereix que es podrien considerar receptes mèdiques. El fet que, d'entrada, siguin un reguitzell de paraules sense sentit, podria suggerir un sentit jocós; com si, a la manera de Metge, volguessin fer una paròdia de les paraules incomprensibles que deien els apotecaris i els metges de l’època. 
explica que la seva germana, Amor, està greument malalta. Davant d'aquest problema, Cerverí inicia un discurs sobre com confeccionar un xarop que la podria curar. En les seves explicacions, aviat queda clar que, per a la seva recepta, no calen productes o tècniques mèdiques convencionals, sinó les qualitats de les dames més rellevants de la Catalunya del seu temps. Així, la recepta acaba esdevenint un panegíric de dames catalanes (Cabré 2OII: 22I).

Amb aquest argument, sembla fâcil de fer encaixar aquest poema dins dels límits del gènere del lletovari. D'entrada, perquè el poema pren la forma d'una recepta que ha de servir per curar una malaltia i, després, perquè el mateix protagonista adopta el rol de metge. A més, el component mèdic, malgrat que no és acusat, va més enllà de la utilització de la metàfora de l'amor com a malaltia perquè se’n parla amb uns termes prou «científics»: en efecte, el protagonista es demostra coneixedor de la «simptomatologia mèdica i dels mètodes bàsics de diagnosi» (Cabré 2OII: 2I8).

La recepta de xarop de Cerverí, doncs -tant per la forma de recepta que pren com pel tractament mèdic que proposa-, s'emmarca sense cap dubte dins de la tradició literària dels lletovaris i en compleix les característiques principals. Així i tot, i malgrat ser una obra normativa en aquest sentit, la seva classificació temàtica pot generar perplexitats perquè, malgrat que és un poema que parla d'amor, ho fa des d'un punt de vista fortament moral i amb una estructura diferent que la resta de lletovaris amorosos. En efecte, en aquest poema qui s'ha de curar de la malaltia d'amor no és una dama o un cavaller -com passava en el Mal d'amor de Pere March, La consolació d'Icart, el Lletovari de Basset o, fins i tot, en el mateix Espill-, sinó que és la mateixa personificació de l'amor. Per dirho més clar: qui està malalt és l'amor i, si està malalt, és perquè els cortesans ja no el serveixen com cal. Davant d'aquest canvi de perspectiva, sembla evident que ja no s'està parlant de l'amor hereos, sinó que es planteja una al-legoria de la decadència de l'amor com a virtut. El xarop, la solució que proposa el poeta, és exercir les qualitats que, de ben segur, ha de tenir el públic cortesà català que l'està escoltant. El poema, així, s'acaba tornant una mostra de pedagogia de la fina amor en la seva accepció ètica (Cabré 2OII: 220 i 223).

En la tradició trobadoresca, la metàfora mèdica ja s'havia utilitzat anteriorment en contextos politico-al-legòrics: és el cas de la Metgia d'Aimeric de Peguilhan, datada el I22O (Bohigas I983: 33). Aquest poema elogia l'emperador Frederic II i equipara el monarca amb un gran metge que ha de restaurar els valors cortesos (Riquer I975: 974). Així i tot, és difícil relacionar aquesta composició amb la tradició dels lletovaris perquè no pren forma de recepta, no té un destinatari malalt concret i qui adopta el rol de metge no és el narrador, sinó el personatge elogiat. Amb tot, encara que no es pugui considerar un lletovari, convé tenir-la en compte per la seva proximitat al-legòrica amb $L a$ recepta de xarop de Cerverí i perquè és una bona mostra del gran recorregut poètic que tingué la metàfora mèdica, també en l'ambient literari trobadoresc.

En segon lloc, poc després de la Recepta de xarop de Cerverí s'escriu la Medicina de pecat de Ramon Llull, un tractat moral en vers redactat a Mallorca l'any I3oo. L'obra pren la forma d'una solució medicinal que ha d'ajudar a evitar els pecats i que ha de conduir cap a la salvació de l’ànima. L'esquema de l'obra com a electuari «es fonamenta ... en un motiu recurrent en la literatura pastoral medieval» que consisteix a utilitzar «les metàfores de la malaltia i la medicina espiritual per explicar el pecat i la salvació de l’ànima» (Fernàndez Clot ed. 20I9: 8). Així, el tractat es presenta com un llibre curatiu mitjançant el qual es pot arribar a la salvació. De fet, el mateix autor explica aquestes intencions en el pròleg, on afirma que «contricció, confessió, / encara satisfació, / e la bona temptació, / e oració exament, son medicina e ongent / contra peccat e falliment» (Fernàndez Clot ed. 20I9: II9, vv. I-6). Aquesta mateixa idea queda refermada en el colofó de l'obra, moment en el qual Llull insisteix en la funció del seu tractat moral: «qui-s en peccat e-xir en vol, / ab est escrit, a son poder; / car ab el orá mantener / la fi a la qual es creat, / e·n sabrá ixir de peccat» (Fernàndez Clot ed. 20I9: 367 , vv. 5862-5866). 
En aquest sentit, la Medicina de pecat ofereix recursos als fidels cristians per demanar perdó pels pecats comesos i preveure futures temptacions. Per fer-ho, proporciona coneixements doctrinals que han de permetre que els lectors aprenguin a viure d'acord amb els manaments de Déu. Amb tot, l'estratègia de Llull no és crear una obra de consulta, sinó proposar al lector un conjunt d'exercicis espirituals que l'han de portar a la salvació. Així, divideix l'obra en cinc parts que no són altra cosa que els cinc remeis contra el pecat o, dit d'altra manera, els cinc estadis curatius que ha de complir el bon cristià (Fernàndez Clot 2018: 396).

Malgrat que, evidentment, Llull no utilitza el motiu de la medicina per representar metafòricament l'enamorament i la seva curació, és rellevant destacar que utilitza aquesta mateixa idea per expressar un altre concepte abstracte com és el pecat -la malaltia-i la salvació de l'ànima -la curació. Ho fa, a més, mitjançant un narrador que es pot entendre com un guia en el procés espiritual que ha de viure el lector i que, en aquest sentit, es pot equiparar al metge. ${ }^{9} \mathrm{Amb}$ tot, cal advertir que l'obra de Llull té una envergadura i una complexitat molt superiors a les de qualsevol altra composició que hem tractat fins ara - potser amb l'excepció de l'Espill- i, per tant, no s'hauria de considerar una obra prototípica de la tradició dels receptaris, tot i que faci servir alguns del trets descrits a $§ 2$.

Finalment, cal examinar el poema Contra fortuna adversa de Ferran d'Ayerbe, escrit als volts del I457. Originari de la Vall de Cofrents, Ayerbe va ser metge i, el I465, va ser nomenat protometge del rei Pere el Conestable. Aquest poema s'escriu amb motiu d'una epidèmia que caigué sobre Barcelona i que podria ser la del I457 (Ferrando I983). Amb vuit estrofes de vuit versos i una tornada de quatre, el poeta, tot i que diu que és «novell» $\mathrm{i}$ «tendre» en l'ofici de la medicina, es disposa a parlar dels estralls de la pesta de Barcelona, que molts anomenen «fortuna adversa».

La composició comença amb una enumeració de les queixes de la població davant de la pesta: diuen que la malaltia els perjudica, que els causa grans dolors i que és tan nociva que, si fos possible, corrompria el «cel empir» només amb l'alè (RIALC vv. 33-34). Com a reacció a aquests retrets, el poeta predica que no han de culpar la mala fortuna de la seva desgràcia, sinó sospirar i plorar perquè, al capdavall, la malaltia ve de la seva «superba planta»: considera que la causa d'aquest mal no és la fortuna maligna, sinó els pecats de la població. En aquest sentit, el remei que ha de curarlos és l'esmena dels vicis i la contrició davant de Déu, que ha provocat aquest mal per castigar-los. En lloc de lamentar-se, doncs, el poeta anima la població a pensar en la pesta no com un infortuni, sinó com una oportunitat per a l'esmena. Així, diu ell, la terra esdevindrà purgatori. La composició acaba amb una pregària a la Mare de Déu, a qui es demana que redreci aviat Barcelona i vingui en el seu auxili.

Malgrat que el poema parla d'una epidèmia, la seva connexió amb el gènere del lletovari és força feble: no pretén ser una recepta farmacèutica, sinó que, més aviat, busca esmenar les creences de la població sobre la pesta. Així i tot, mereix ser considerat en aquest treball perquè el poeta dona instruccions morals per curar una malaltia des d'un rol de metge.

9. Recordem que les analogies mèdiques són molt productives en la literatura religiosa, sobretot a partir de la regulació de la pràctica de la confessió, el I2I5: el malalt se sol equiparar amb el pecador, el metge amb Jesús -o amb un religiós- i el cos amb l'ànima. Per exemple, De quinque septenis d'Hug de Sant Víctor tracta els vicis com si fossin una malaltia i Déu com si fos un metge (Fernàndez Clot, 20I8: 384-85). Es rellevant destacar fins a quin punt la ciència mèdica és una font de símils en diferents àmbits literaris. 


\section{El Lletovari de Joan Basset i la seva connexió amb l'Espill de Jaume Roig}

El

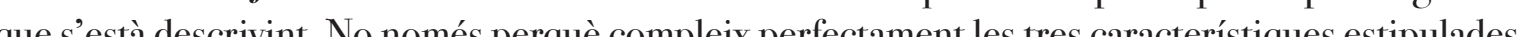
a §2, sinó perquè, a més, és de tema amorós i presenta més connexions amb el món de la medicina que les altres obres d'aquesta temàtica. La forma de recepta que utilitza, l'ús de terminologia mèdica i de metges famosos de l'època, la concreció d'un destinatari que pateix mal d'amors, l'adopció del rol de metge per part del narrador i, fins i tot, el títol de l'obra, la col-loquen directament al centre de la tradició dels lletovaris literaris.

El poema, de 195 versos tetrasil-làbics, s'inicia amb l'exposició del tema: l'amic Guerau -que a la rúbrica s'identifica amb Guerau de Maçanet, poeta coetani de l'autor- està malalt d'amor i demana que l'autor li enviï un lletovari que el pugui curar. Basset entra en matèria tot seguit i, d'entrada, ja deixa clar que la ciència mèdica no és una arma vàlida per combatre aquesta malaltia. Tot i aquest rebuig, s'afanya a demostrar que és coneixedor dels rudiments bàsics de l'ofici i llista, amb un to distès, algunes pràctiques i ingredients farmacològics de l'època combinats amb els noms d'alguns metges famosos: ${ }^{\text {: }}$

$$
\begin{array}{ll} 
& \text { En tal strena, } \\
\text { may val sagnia, } & \text { ne y val momia, } \\
& \text { ne fin ruibarbre, } \\
& \text { ne polç de marbre, } \\
25 & \text { ne blanch gingebre } \\
& \text { no y fa valença, } \\
\text { ne y fa remença } \\
\text { l'aut Galièn, } \\
\text { ne perlamén } \\
\text { may d'Avicenna, } \\
\text { e such de penna } \\
\text { tanpauch no y val }{ }^{\text {I. }} .
\end{array}
$$

Després d'aquesta exhibició, Basset decideix consultar l'opinió dels poetes que, al capdavall, són la veu de la tradició i qui s'ha encarregat des de sempre d'aquesta mena d'afers del cor. Trenca, llavors, el ritme mètric tetrasil-làbic constant que utilitza en la resta de la composició i introdueix dues citacions directes ${ }^{12}$ de dos suposats poetes que han parlat d'amor: Vilarfrau i Ramon Novell, ${ }^{13}$

IO. Rosanna Cantavella (I993: I99) vinculava aquesta primera part del poema amb un sonet atribuït a Boccaccio (el número LXXXVI de les Rime), que s’inicia amb els versos següents: «Ippocrate, Avicenna o Galieno, / diamante, zafir, perla o rubino, / brettonica, marrobio o rosmarino, / psalmo, evangelio ed orazion vien meno» (Segre ed., I966: 74I42). D’entrada, adverteix que tots dos poemes citen metges famosos de l'època i que coincideixen mencionant Avicenna i Galè. Després, observa que tant el sonet com el Lletovari parlen de la medicina per acabar rebutjant-la: d'una banda, Boccaccio utilitza la metàfora mèdica com a hipèrbole -el seu amor és tan profund que el saber mèdic és incapaç de guarir-lo-i, de l'altra, Basset, amb un to molt més jocós, també acaba bandejant els metges.

II. Edició de l'autora. Seguim els criteris d'Els Nostres Clàssics.

I2. Aquesta estratègia poètica connecta el Lletovari amb d'altres peces que utilitzen el recurs de la citació, com el Breviari d'amor, de Matfre Ermengaud, la Passio amoris secundum Ovidium, de Jordi de Sant Jordi (RAO I64.I4), o el poema Tant mon voler, de Pere Torroella (RAO I80.28), entre d'altres. Aquesta tècnica -i, sobretot, la invocació d'autoritats, que és la modalitat que utilitza Basset- és freqüent a tota la Romània. Per a més informació sobre els poemes amb citacions, vegeu Simó (2OI2).

I3. No es tenen notícies documentals de cap d'aquests dos poetes. 
que afirmen que l'amor només es pot curar amb la correspondència de l'estimada, i que recomanen la perseverança de l'enamorat.

Encara que Basset dona una credibilitat major als poetes que als metges, també els acaba posant en dubte com a autoritats vàlides. La solució que més el convenç és molt més dràstica i passa pel rebuig de la passió d'amor i pel vituperi del gènere femení que, al capdavall, és qui ha provocat la malaltia. La recepta pròpiament dita, doncs, consisteix a donar consells conductuals sobre com tractar les dones: cal desenamorar-se’n i enganyar-les abans d'esdevenir víctima del seu engany.

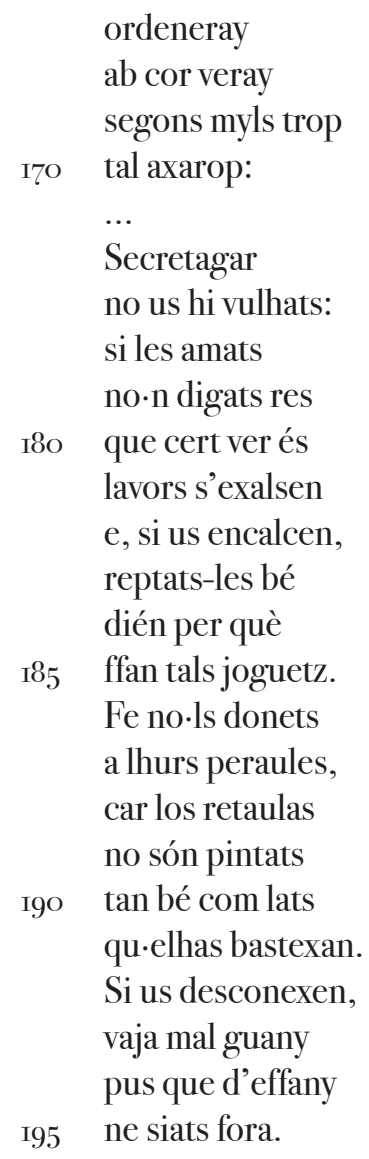

La connexió de l'obra amb la medicina real, com la majoria de lletovaris, és molt indirecta i no deixa de ser un pretext retòric. Així i tot, aquest és el lletovari contra el mal d'amor que més connecta amb el món de la medicina, encara que sigui per rebutjar-la: la terminologia mèdica que utilitza, l'apel-lació a les autoritats mèdiques i la declaració del narrador que vol preparar un lletovari o un xarop el vinculen molt directament amb els receptaris mèdics. Només La medicina de Metge i el Lletovari anònim del Cançoner de l'Ateneu Barcelonès, tots dos paròdics, el superen en aquest sentit.

D’altra banda, la connexió entre el Lletovari de Joan Basset i l'Espill de Jaume Roig és inevitable. Primer, el vers tetrasil-làbic en clau satiricocòmica de Basset constitueix l'únic precedent conservat del metre que Roig utilitza en l'Espill (Torró 2OI5: 272). Totes dues obres estan escrites en noves rimades, un gènere que es va cultivar a la Corona d'Aragó des del segle XIII fins al XV, i que comprèn les narracions en vers escrites en versos isosil-làbics apariats i destinades tant a la lectura com a la recitació (Pacheco 2007: IO). Malgrat que els models principals de les narracions en vers que provenien de la tradició francesa i occitana es van escriure majoritàriament en versos de vuit síl-labes -els romans de Chrétien de Troyes, els Lais de Maria de França o la Flamenca, per 
exemple-, també es troben noves rimades escrites en versos més breus i àgils (Riquer i964, II: I2). De fet, el tetrasíllab és un metre que permet arribar a la posició de rima el doble de vegades i que, a més, produeix un martelleig fònic i una sintaxi sincopada que resulta molt adequada per a l'objectiu còmic que volen aconseguir tant Basset com Roig. ${ }^{14}$

En segon lloc, la misogínia del Lletovari també el connecta amb l’Espill que, com és ben sabut, es complau en la vituperació de la dona i la utilitza com a estratègia per apartar els homes del mal d'amor. És més, totes dues obres acaben proposant una solució mèdica similar: segons Basset, el que cal fer és desenamorar-se de les dones i enganyar-les com elles fan amb els homes i, segons Roig, com concreta en el llibre quart de la seva obra, és necessària «la castedat a ultrança» i un «model de vida ascètica» (Carré ed. 2006: 58).

Aquestes semblances podrien generar dubtes sobre si el mateix Espill es podria incloure en el gènere dels lletovaris que s'està definint. Certament, l'obra s'escriu, en part, com a advertència a Baltasar Bou, jove inexpert i possible enamorat, perquè eviti les dones i s'estalviï, així, molts maldecaps i febres. D'aquesta manera, l'Espill es podria entendre com un tractat contra l'amor i, de fet, Torró (2015: 272) va més enllà i afirma que s'escriu “en la forma que a l'edat mitjana es coneixia com a lletovari (literalment, 'tractat sobre remeis')". Basant-se en la consulta inicial, Torró argumenta que l'Espill es podria entendre com una resposta, un "rescrit", a una demanda prèvia del cavaller Joan Fabra que, tal com diu el vers tercer de l'obra, exhibeix un "gentil atreviment" (Carré ed 2006: 7O vv. 3) quan es troba entre dones -i que, per tant, necessita ajuda contra l'amor.

També és destacable que, a l'Espill, Jaume Roig «no amaga la condició de metge ni tampoc la seva formació universitària» (Carré 2015: 286). En diversos moments, s'usa terminologia galènica o s'esmenten pràctiques mèdiques que concorden amb els usos de l'època, com podrien ser les dietes. A més, s’afirma que el narrador pateix la malaltia de l'amor. L'obra, en aquest sentit, també està molt relacionada amb els receptaris.

Així i tot, la gran envergadura de l'Espill podria fer dubtar sobre la pertinença de l'obra al gènere. La seva complexitat argumental i temàtica la fan transcendir composicions com la de March, Icart o Basset que, per la seva naturalesa més breu i senzilla, s'hi emmotllen més fâcilment. De fet, com que l'Espillés un relat pseudoautobiogràfic del sofriment del narrador, amb un somni consolatori i una transformació final, se sol catalogar, més aviat, com a literatura consolatòria. Torró (2OI5: 28I-283) també ha destacat la connexió de l'obra amb altres gèneres com la comèdia, la facècia, l'aforisme i, sobretot, la sàtira. La Medicina de pecat de Ramon Llull presenta un problema similar a l'hora d'etiquetar-se com a lletovari perquè, si bé té connexions evidents amb el gènere, demostra una complexitat i una ambició que va més enllà de les intencions de la resta d'obres que fan servir forma de recepta.

\section{Una nova definició del gènere}

Després d'haver examinat el corpus de lletovaris literaris catalans, es fa evident el fil conductor que lliga totes les peces que l'integren. Malgrat la seva diversitat temàtica i formal, comparteixen les característiques que hem apuntat a \$2 i que s'han confirmat amb l'ampliació del corpus: són poemes que pretenen ser una recepta mèdica, tenen un narrador que adopta el rol de metge, un destinatari malalt, i utilitzen en molts casos terminologia mèdica.

I4. El vers tetrasil-làbic emprat en sèries isosil-làbiques és prou escàs en la poesia medieval, i per això destaca la relació entre el poema de Basset i l'obra de Roig. Amb tot, hi ha altres obres que utilitzen aquesta mètrica, com el prefaci al Mirall de trobar de Berenguer d'Anoia i dues profecies d'Anselm Turmeda (Parramon I992: 19, 239-264). 
La particularitat fonamental dels lletovaris, doncs, és la seva connexió amb el món de la medicina i, en especial, amb el gènere del receptari mèdic: totes les obres analitzades entren en el joc de ferse passar per un text d'instruccions de sanitat, i aquesta forma de recepta no es pot entendre sense el seu predecessor mèdic, que es popularitza a la segona meitat del segle XIII. Aquesta adscripció dels lletovaris a unes circumstàncies culturals concretes, explica per què no se’n troben mostres al nucli de l'època trobadoresca. Certament, no són lletovaris tots els poemes que connecten amb la medicina o n'utilitzen imatges -la salut ha estat un tema poètic immemorial que ja havien tractat directament o indirectament autors com Ovidi o Aimeric de Peguilhan-, sinó tan sols aquells que imiten la forma de recepta. Així doncs, el lletovari literari no es pot concebre sense una prèvia popularització del receptari mèdic, que li fa de model.

El gènere entès d'aquesta manera no es comença a cultivar fins a la segona meitat del segle XIII. ${ }^{15}$ Potser per aquest caràcter tardà, es pot explicar per què no va ser mai descrit als tractats retòrics de finals del XIII i principis del XIV: si en el moment de la redacció d'aquests tractats els lletovaris eren un assumpte d'actualitat, és probable que no es percebessin com una unitat o que no se'ls donés prou valor per descriure'ls i classificar-los. Així doncs, aquesta manca de codificació no ha de fer desistir de l'empresa d'estudiar aquest conjunt de peces com un tot.

La bibliografia crítica ja havia tingut aquesta intuïció d'unitat i havia parlat del gènere o de la tradició dels lletovaris literaris. Així i tot, poques vegades l'havia estudiat amb profunditat o n’havia definit els límits. Gràcies a l'anàlisi del corpus recollit, podem constatar que, al contrari del que s'havia afirmat anteriorment, els lletovaris són molt heterogenis i no només utilitzen la metàfora mèdica per parlar de l'amor. Encara que alguns poemes analitzats sí que aconsellen el lector en la línia dels Remedia amoris -com el de March, Icart, Basset i, fins a cert punt, el de Roig-, també n'hi ha d'altres que es riuen dels metges o que pretenen resoldre problemes de salut de l'ànima. La Medicina de Metge, per exemple, proposa remeis estrafolaris per riure's dels apotecaris i la Medicina de pecat de Ramon Llull vol portar les ànimes a la salvació. Així i tot, ens podríem preguntar si els lletovaris contra el mal d'amor podrien ser la branca predominant en aquesta tradició: encara que no siguin significativament els més nombrosos -perquè només se’n conserven tres, si es descarta l'Espill, o quatre, si es té en compte aquest- sembla que alguns dels lletovaris paròdics en facin befa i que, per tant, els tinguin presents a l'hora d'escriure. Si fos així, tindríem indicis per creure que la tradició dels lletovaris amorosos estava formada per més obres de les que ens han pervingut.

Encara que l'amor pugui semblar el tema més prototípic d'aquesta tradició, és evident que no és l'únic i que no hauria de convertir-se en una de les fronteres del gènere: el lletovari demana una nova definició que, en lloc de fer èmfasi en una temàtica concreta, reflecteixi els trets bàsics descrits a $\S_{2}$ i en destaqui la connexió amb el receptari mèdic.

La definició proposada, doncs, podria ser la següent: un lletovari literari és una obra en vers que, recreant la forma d'una recepta mèdica, dona consells a un lector pretesament malalt des de la perspectiva d'un narrador que adopta el rol de metge.

El corpus d'obres que hem comentat no és una llista tancada de textos i la discussió sobre el seu grau d’identificació amb el gènere continua oberta. L'Espilli la Medicina de pecat, per exemple, són dues composicions que, per la seva envergadura i complexitat, transcendeixen la majoria de poemes del corpus i que, per tant, encara que s'hi relacionen directament, és dubtós que es puguin

I5. A més, només es conserven dues peces escrites en aquest segle, totes dues morals: la Recepta de xarop de Cerverí i la Medicina de pecat de Llull. Això podria fer-nos pensar que la tradició dels lletovaris no va agafar una embranzida palpable fins ben entrat el segle xIV. Amb tot, es fa difícil de dir, perquè molt probablement hi havia hagut altres composicions d'aquestes característiques que no s'han conservat. 
etiquetar com a lletovaris. Al seu torn, el Lletovari de Joan Basset és una composició especialment prototípica d'aquesta tradició. No només perquè en compleix les característiques més significatives -l'estructura de recepta, el rol de metge del narrador, el destinatari malalt i la terminologia mèdica-, sinó perquè, a més, es revela com el lletovari contra el mal d'amor amb més connexions amb el món de la medicina. Igualment, les semblances entre el poema de Basset i l'Espill evidencien la connexió d'aquesta segona obra amb el gènere dels lletovaris i fan plantejar fins a quin punt aquesta tradició -que, fins ara, gairebé havia passat desapercebuda- podria ser un dels embrions d'obres tan rellevants com la de Roig. 


\section{Obres citades}

Bohigas, Pere. 1983. 'El Letovari de fra Joan Basset', in Miscel.lània Aramon i Serra: estudis de llengua i literatura catalanes oferts a R. Aramon i Serra en el seu setantè aniversari (Barcelona: Curial), III: $3^{\mathrm{I}-37}$

Bohigas, Pere. I988. Lírica trobadoresca del segle XV: Joan Basset i altres poetes inèdits del Cançoner Vega-Aguiló (València: IFV; Barcelona: Publicacions de l’Abadia de Montserrat)

Cabré, Lluís (ed.). 1993. Pere March Obra completa (Barcelona: Barcino)

Cabré, Lluís. 20I4. 'Vida i obra de Bernat Metge', in Història de la literatura catalana, ed. by Àlex Broch (Barcelona: Enciclopèdia Catalana; Editorial Barcino; Ajuntament de Barcelona), II: Literatura medieval (II): Segles XIV-XV, ed. by Lola Badia, pp. 192-2O2

Cabré, Miriam. 20Ir. Cerverí de Girona: un trobador al servei de Pere el Gran (Barcelona: Publicacions de la Universitat de Barcelona)

Cabré, Miriam. 20I3. 'La lírica d'arrel trobadoresca', in Història de la literatura catalana, ed. by Alex Broch (Barcelona: Enciclopèdia Catalana; Editorial Barcino; Ajuntament de Barcelona), I: Literatura medieval (I): Dels orígens al segle XIV, ed. by Lola Badia, pp. 219-2g6

Carré, Antònia. 1996. 'La medicina com a rerefons cultural de l'Espill de Jaume Roig', in Jaume Roig i Cristòfor Despuig: dos assaigs sobre cultura i literatura dels segles XVi XVI, Antònia Carré and Josep Solervicens (Vic: Eumo), pp. 7-7I

Carré, Antònia (ed.). 20o6. Jaume Roig Espill (Barcelona: Quaderns Crema)

Carré, Antònia. 20I5. 'L'Espill com a mirall d'època', in Història de la literatura catalana, ed. by Alex Broch (Barcelona: Enciclopèdia Catalana; Editorial Barcino; Ajuntament de Barcelona), III: Literatura medieval (III): Segle XV, ed. by Lola Badia, pp. 284-292

Carré, Antònia. 202I. 'Els sequaços literaris de Guillem Metge', in Qui fruit ne sap collir': Homenatge a Lola Badia, ed. by Anna Alberni et al. (Barcelona: Universitat de Barcelona; Editorial Barcino), I: $145^{-1} 5^{6}$

Cantavella, Rosanna. 1993. 'Terapèutiques de l'amor hereos a la literatura catalana medieval', in Actes del Novè Col-loqui Internacional de Llengua i Literatura Catalanes, Alacant-Elx i99i, ed. by Antoni Ferrando, Lluís Meseguer and Rafael Alemany (Barcelona: Publicacions de l'Abadia de Montserrat), II: $\mathrm{I} 9 \mathrm{I}-2 \mathrm{O} 7$

Capellani, Andrea. I985. De Amore: tratado sobre el amor, ed. by. Inés Creixell Vidal-Quadras (Barcelona: Sirmio)

Cifuentes, Lluís. 2002. La ciència en català a l'Edat Mitjana i el Renaixement (Barcelona: Universitat de Barcelona; Palma: Universitat de les Illes Balears)

Cifuentes, Lluís. 20I6. 'El receptari mèdic baixmedieval i renaixentista: un gènere vernacle', in Els manuscrits, el saber i les lletres a la Corona d'Aragó (1250-150o), ed. by Lola Badia et al. (Barcelona: Publicacions de l'Abadia de Montserrat), pp. IO3-I59

DCVB: Alcover, Antoni Maria; Moll, Francesc de Borja. I964-I969. Diccionari català-valenciàbalear: inventari lexicogràfic i etimològic de la llengua catalana en totes les seves formes literàries 
i dialectals, recollides dels documents i textos antics i moderns, i del parlarvivent, 2nd ed.,. IO vols (Palma: Editorial Moll) < https://dcrb.iec.cat/>

DIEC. 2007-. Diccionari de la llengua catalana (Barcelona: Institut d'Estudis Catalans) $<\underline{\mathrm{http}} / / /$ $\underline{\text { dlc.iec.cat }>}$

Fernàndez Clot, Anna. 20I8. 'La Medicina de pecat de Ramon Llull, un electuari moral en vers', in Actes del Congrés de Clausura de l'Any Llull: Ramon Llull, pensadori escriptor, Barcelona 2016, ed. by Lola Badia, Joan Santanach and Albert Soler (Barcelona: Universitat de Barcelona; Palma: Universitat de les Illes Balears), pp. 38I-400

Fernàndez Clot, Anna (ed.). 20I9. Ramon Llull Medicina de pecat, NEORL, 16 (Barcelona: Publicacions de l'Abadia de Montserrat)

McVaugh, Michael; Giralt, Sebastià. 2OII. Arnau de Vilanova Tractat sobre l'amor heroic (Barcelona: Barcino)

Pacheco, Arseni (ed.). 2007. 'Les noves rimades i les codolades entre el roman i la novel.la', in Homenatge a Joseph Gulsoy (Barcelona: Fundació Congrés de Cultura Catalana; Institució de les Lletres Catalanes), III: 5-20 <https://ja.cat/bPjSq >

Parramon, Jordi. 1992. Repertori mètric de la poesia catalana medieval (Barcelona: Curial; Publicacions de l'Abadia de Montserrat)

RAO: Parramon, Jordi. 1992. 'Repertori d'autors i obres de la poesia catalana medieval', in Repertori mètric de la poesia catalana medieval (Barcelona: Curial; Publicacions de l'Abadia de Montserrat), pp. 273-319

RIALC: Repertorio informatizzato dell'antica letteratura catalana (Napoli: Università di Napoli Federico II) <http://www.rialc.unina.it $>$ [accessed I9-06-202O]

Riquer, Martí de. 1975. Los trovadores: historia literaria y textos, 3 vols (Barcelona: Ariel)

Riquer, Martí de. 1964. Història de la literatura catalana: part antiga, 3 vols (Barcelona: Ariel)

Romeu, Josep. 1994. 'Guerau de Maçanet, entre la realitat lírica i la identificació hipotètica', in his Lectura de textos medievals i renaixentistes (València: IIFV; Barcelona: Publiocacions de l'Abadia de Montserrat), pp. 63-IOI (Ist ed. I98I)

Segre, Cesare (ed.). r966. Giovanni Boccaccio Opere (Milano: Mursia \& C)

Simó, Meritxell. 20I2. Jaume Massó i Torrents: la cançó provençal en la literatura catalana cent anys després (Firenze: Edizioni del Galluzzo-Fondazione Ezio Franceschini)

Torró, Jaume. 20I4. 'La poesia cortesana', in Història de la literatura catalana, ed. by Àlex Broch (Barcelona: Enciclopèdia Catalana; Editorial Barcino; Ajuntament de Barcelona), II: Literatura medieval (II): Segles XIV-XV, ed. by Lola Badia, pp. 261-352

Torró, Jaume. 20I5. 'Jaume Roig i la tradició satírica', in Història de la literatura catalana, ed. by Àlex Broch (Barcelona: Enciclopèdia Catalana; Editorial Barcino; Ajuntament de Barcelona), III: Literatura medieval (III): Segle XV, ed. by Lola Badia, pp. 266-283

Valsalobre, Pep. 2005. 'Apotecaris i receptes en la literatura catalana antiga', Mot so Razo, 4: 34-46 $<$ https://raco.cat/index.php/Msr/article/view/254705>

Wack, Mary F. 1990. Lovesickness in the Middle Ages: The 'Viaticum' and its Commentaries (Philadelphia: University of Pennsylvania Press) 